\title{
Molecular Identification and Characterization of Vibrio species and Mycobacterium species in Wild and Cultured Marine Fish from the Eastern Mediterranean Sea
}

\author{
Yael Regev ${ }^{1,2}$, Nadav Davidovich ${ }^{3}\left({ }^{\circ}\right.$, Ran Berzak ${ }^{1,2}$, Stanley C. K. Lau ${ }^{4}$, Aviad P. Scheinin ${ }^{1,2}$, \\ Dan Tchernov ${ }^{1,2}$ and Danny Morick 1,2,* \\ 1 Department of Marine Biology, Leon H. Charney School of Marine Sciences, University of Haifa, \\ Haifa 3498838, Israel; yaelchac@gmail.com (Y.R.); ranberzak@gmail.com (R.B.); \\ shani.aviad@gmail.com (A.P.S.); dtchernov@univ.haifa.ac.il (D.T.) \\ 2 Morris Kahn Marine Research Station, University of Haifa, Haifa 3498838, Israel \\ 3 Israeli Veterinary Services, Bet Dagan 5025001, Israel; Nadavd@moag.gov.il \\ 4 Department of Ocean Science, The Hong Kong University of Science and Technology, Clear Water Bay, \\ Kowloon, Hong Kong; scklau@ust.hk \\ * Correspondence: dmorick@univ.haifa.ac.il
}

Received: 16 April 2020; Accepted: 4 June 2020; Published: 7 June 2020

\begin{abstract}
In contrast to numerous documented pathogens and infectious diseases of aquaculture, there is a lack of baseline data and information regarding pathogenic agents' prevalence in wild marine fish populations. This study focused on two common fish pathogenic microorganisms, namely Mycobacterium species and Vibrio species, both of which are known to be major causes of fish loss, occasionally to the extent of being a limiting factor in fish production. Both microorganisms are known as zoonotic agents. In total, 210 wild marine indigenous and Lessepsian fish from four different species from the eastern Mediterranean Sea were sampled and tested for Vibrio species and Mycobacterium species during a two-year period (2016-2017). Using PCR with 16S rRNA primers, we detected different strain variations of Mycobacterium species and Vibrio species and, based on the sequencing results, the overall prevalence for Vibrio species in wild fish in 2016 was significantly higher compared to 2017. No significant difference was detected for Mycobacterium species prevalence in wild fish between 2016 and 2017. In addition, 72 gilthead seabream (Sparus aurata) from an Israeli offshore marine farm were also examined during the two-year period (2017-2018). The results suggest that Mycobacterium species prevalence was significantly higher in 2018, while in 2017 there was no positive results for Mycobacterium species. In addition, there was no significant difference between both years in regard to the prevalence of Vibrio species for maricultured fish. These results highlight the necessity of continuous molecular monitoring in order to evaluate the prevalence of pathogenic microorganisms in both wild and cultured fish populations.
\end{abstract}

Keywords: Vibrio; Mycobacterium; zoonotic microorganisms; Mediterranean Sea; wild fish; farmed fish

\section{Introduction}

Over the past few decades, there has been a worldwide increase in reports of diseases affecting marine organisms of different taxa [1]. Climate change is affecting the marine ecosystem, which is already subjected to many anthropogenic disturbances, such as overfishing, pollution and habitat destruction. Climate warming can increase pathogen development and their survival rates, disease transmission and host susceptibility [2]. Environmental conditions play a crucial role not only in 
pathogen transmission, but also as risk factors for the occurrence of clinical diseases. Unlike mammals that regulate their internal environments, most fish are poikilotherms with little ability to regulate their core body temperature. In this situation, both the microbe and the host are physiologically tied to the environment they live in and have an optimal temperature range for survival. Extended periods outside the optimal range usually results in death [3]. This is especially true in the Mediterranean Sea, which is one of the biggest reservoirs of biodiversity in the world [4]. Diverse cold and tropical marine fauna combine and mix due to the basin's oceanographic and biogeographical properties and, therefore, might serve as "miniature model" for the world's oceans and provide insights into global patterns of marine ecosystems [5].

Although aquaculture production has increased dramatically, fish consumption still largely depends on fisheries [6]. Wild fish have an important ecological role in the ecosystem and economic role as a major protein source for humans [7]. A wide range of marine pathogens from aquaculture is well documented, but there remains a lack of baseline data and information regarding pathogenic agents' prevalence in the wild fish population [8]. On the other hand, aquaculture is a fast-growing industry for the production of high protein-sourced foods, including fish production [9]. This growth is accompanied by concerns from both the public and private sectors [9], as fish production is commonly associated with serious environmental impacts (e.g., water pollution, pathogen transmission, and temperature changes). Mariculture production is usually as crowded and intensive production ponds. Fish are routinely treated and harvested from the walkway or raft around the cages, and boats are used for transportation of feed and for harvest [10]. In Israel, there are several offshore marine farms along the Israeli Mediterranean coastline. Gilthead seabream (Sparus aurata) is the dominant mariculture species, with an annual production in 2018 of 2450 tons, and 2310 tons in 2019 [11]. Global aquaculture production has constantly increased during the last five decades [12]. Although aquaculture in the Mediterranean is considered a relatively young industry, finfish diseases have been reported to cause substantial problems and mortalities among farmed stocks [13]. Two apparent reasons that play a central role in the transmission of infectious pathogens are the farming activity, and the open design of Mediterranean aquaculture systems. As such, the transport of infected farmed fish from hatcheries, infected equipment, staff, and vessels, as well as through water currents, has been the main focus of fish health and biosecurity programs [13]. Infectious agents are also common in marine waters. Bacteria and viruses can be transmitted both horizontally and vertically, due to oceanographic conditions in nearshore environments that are strongly influenced by local conditions [14], and they can reduce commercial species' growth and survivorship or decrease seafood quality. These impacts seem most problematic in the stressful and crowded conditions of aquaculture, which increasingly dominates seafood production as wild fishery production plateaus [15]. It is often difficult to accurately estimate the impacts of diseases on wild populations, especially those of pelagic and subtidal fish species. However, there are a few quantitative data demonstrating that wild species near farms suffer more from infectious diseases than those in other areas. The movement of exotic infectious agents to new areas continues to be a great concern. It is important to note that the exposure of a host to a pathogen does not always result in infection, which, in turn, does not always lead to disease [16]. Moreover, infection may occur geographically far from the immediate vicinity where infection is either detected or disease first becomes evident. These variables make diagnosis and/or pathogen evasion highly problematic.

Zoonotic microorganisms present a global public health concern. Those pathogens are known to cause protracted illness, especially in immuno-compromised individuals [17]. As aquaculture production and the consumption of aquaculture products increase, the possibility of contracting zoonotic infections from either handling or ingesting these products also increases. Disease outbreaks are often related to management factors, such as the quality and quantity of nutrients in the water and high stocking density, which can increase bacterial loading on the external surface of the fish. As a result, diseased fish are more likely to transmit infection to humans [18].

This research focused on two types of bacterial pathogens, namely Vibrio and Mycobacterium, which are known as zoonotic pathogens [17] and are major causes of fish mortality [19]. Vibrio species 
are Gram-negative curved rods that occur naturally in marine, estuarine, and freshwater systems worldwide. They occupy habitats ranging from the deep sea to shallow aquatic environments [20]. More than 70 different Vibrio species are known, 12 of which are recognized as human pathogens [21]. Some species include human and animal pathogens capable of causing gastroenteritis, wound infections, cholera, and fatal septicemia [22]. Infections caused by Vibrio have been observed and documented in marine and estuarine-type fishes. The disease is known to have increased death rates $(>50 \%)$ in fish farms soon after an outbreak [23]. Fish vibriosis usually start with sluggishness and a loss of appetite. The disease may cause discoloration and eventual decay of the skin. Swollen sores may appear on the body, and in many cases protrude through the skin surface. Another symptom is redness around the fins and mouth. When the disease becomes systemic, it can cause exophthalmia, and the gut and rectum may be bloody and filled with fluid [23]. Vibrio sp. cause some of the most significant infections of marine finfish. All marine fish are probably susceptible to at least one species. Vibrio sp. have been infrequently isolated from freshwater aquarium fish and freshwater salmonids that have been fed marine offal [24]. Vibrio sp. are typically facultative pathogens that can readily survive and multiply in the environment, although the relative pathogenicity of environmental versus fish isolates is uncertain. Vibrio sp. are usually isolated from the mucosal surfaces and internal organs of clinically healthy fish. The highest environmental prevalence is in organically-polluted water and high salinity. A major predisposing risk factor for most types of fish-vibriosis is high water temperature. Crowding, organic pollution, and other stressors can also precipitate diseases outbreaks. Vibrio strains also vary considerably in virulence, and some of them can cause disease without any predisposing stress. Some Vibrio species produce hemolysins (which may cause anemia) and proteases (which may cause muscle damage) [24].

Mycobacteria (Family Mycobacteriaceae) are pleomorphic, Gram-positive, acid-fast, aerobic, non-motile rods [17]. Fish mycobacteriosis is caused by non-tuberculous mycobacteria (NTM), and considered among the most chronic diseases occurring in aquatic animals [25]. NTM is a group of more than 150 different species with distinct virulence features [26]. In addition, fish mycobacteriosis is a chronic disease that has substantial economic consequences, as infections may significantly decrease production and trade. Some fish NTM are highly virulent and zoonotic [17]. Typical signs of Mycobacterium in fish are weight loss or emaciation, scale loss, ulcerations or hemorrhage along the body wall, granulomas, poor appetite and attitude, and often a history of reproductive problems [27]. Both external and internal clinical signs caused by each pathogen are dependent on the host species, age of the fish, and stage of the disease (acute, chronic, and sub-clinic carrier); the signs are not always correlated or present at all [28]. Mycobacterium marinum was first isolated in 1926 from several marine fish species [24]; it is the most common etiological agent of fish mycobacteriosis [24]. Other significant mycobacteria reported in marine fish are Mycobacterium chelonae and Mycobacterium fortuitum. NTM are saprophytes that reside in both soil and water, where they can survive for years. Commonly, gross examination of infected fish reveals grayish to white granulomatous nodules in various internal organs, mainly the spleen, liver, and kidney. However, in some cases, external signs may be present in the form of dermal ulceration [24]. The objectives of this study were: (a) to evaluate the prevalence of Vibrio sp. and Mycobacterium sp. in wild and cultured marine fish species; (b) to compare pathogen prevalence between different years in farmed and wild fish; (c) to compare pathogen prevalence in different internal organs and maturity age; (d) to identify different strain variations of Vibrio sp. and Mycobacterium sp. in wild and cultured fish; and (e) to assess transmission of the pathogens from wild to cultured fish and vice versa.

\section{Materials and Methods}

\subsection{Fish and Tissue Sampling}

Four wild fish species: striped red mullet (Mullus surmuletus), Randall's threadfin bream (Nemipterus randalli), lizardfish (Saurida lessepsianus), and round sardinella (Sardinella aurita) were 
caught by trawlers and fishermen. Fish were collected at four ports along the Israeli Mediterranean shoreline: Acre, Kishon, Jaffa, and Ashdod (Figure 1). In addition, gilthead seabream (Sparus aurata) specimens were sampled during their growth period from a fish farm located $12 \mathrm{~km}$ offshore in the southern area of the Israeli Mediterranean Sea. All wild specimens were sampled during 2016-2017, and the cultured S. aurata were sampled during 2017-2018 (Tables 1 and 2). Fish were placed on ice immediately on the boat and transferred to the laboratory where weight, total length, and visual inspections were carried out. It should be mentioned that the fish were obtained at the ports and nearby fish markets, but the exact fish capture sites are not recorded in this study. All specimens were aseptically dissected for tissue sample collection according to fish necropsy protocol [29]. All samples were kept frozen at $-80^{\circ} \mathrm{C}$ until further analysis. From each fish specimen, liver and kidney tissues were collected and kept frozen at $-80^{\circ} \mathrm{C}$ until use.

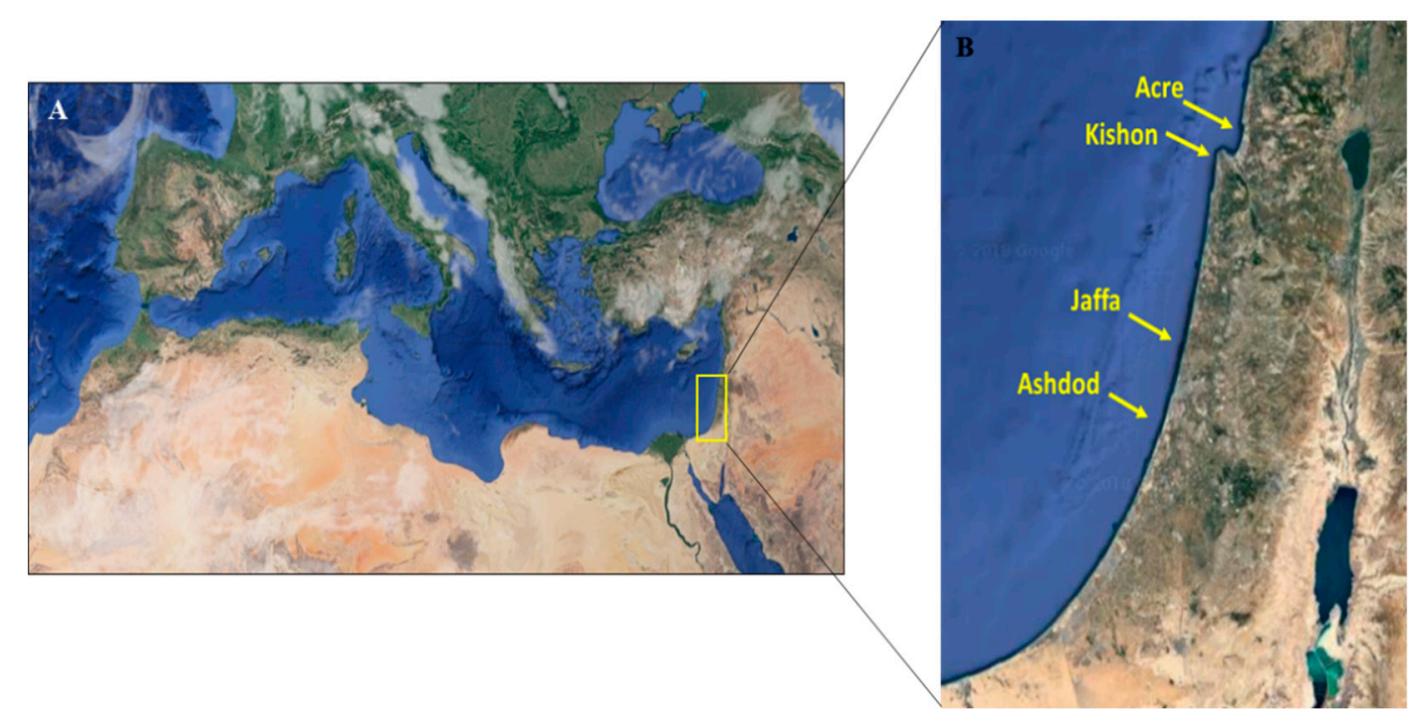

Figure 1. Geographical distribution of the sampling locations described in this study: (A) sampling area is in the most eastern basin of the Mediterranean Sea; and (B) fish were sampled from four fishing ports along the Israeli coast-two in the north (Acre and Kishon) and two in the south (Jaffa and Ashdod). Template map source: Google Earth.

Table 1. Wild fish organisms sampled and analyzed in this study. Total number of specimens tested and number of wild fish sampled from each sampling site in 2016 and 2017.

\begin{tabular}{|c|c|c|c|c|c|c|c|}
\hline Year & Family, Species & Origin * & Acre & Kishon & Jaffa & Ashdod & Total \\
\hline \multirow{5}{*}{2016} & Mulidae & & & & & & \\
\hline & $\begin{array}{l}\text { Mullus surmuletus } \\
\text { Nemipteridae }\end{array}$ & $\mathrm{m}$ & 3 & 13 & 3 & 3 & 22 \\
\hline & $\begin{array}{l}\text { Nemipterus randalli } \\
\text { Synodonitidae }\end{array}$ & 1 & 3 & 13 & 10 & 3 & 29 \\
\hline & $\begin{array}{c}\text { Saurida lessepsianus } \\
\text { Clupeidae }\end{array}$ & 1 & 9 & 13 & 13 & 3 & 38 \\
\hline & Sardinella aurita & $\mathrm{m}$ & 3 & 11 & 10 & nc & 24 \\
\hline \multirow{4}{*}{2017} & $\begin{array}{c}\text { Mulidae } \\
\text { Mullus surmuletus } \\
\text { Nemipteridae }\end{array}$ & $\mathrm{m}$ & nc & 15 & nc & nc & 15 \\
\hline & $\begin{array}{l}\text { Nemipterus randalli } \\
\text { Synodonitidae }\end{array}$ & 1 & nc & 15 & 15 & 12 & 42 \\
\hline & $\begin{array}{c}\text { Saurida lessepsianus } \\
\text { Clupeidae }\end{array}$ & 1 & nc & nc & 15 & nc & 15 \\
\hline & Sardinella aurita & $\mathrm{m}$ & nc & nc & 20 & 5 & 25 \\
\hline
\end{tabular}

${ }^{*} \mathrm{~m}$, Mediterranean natives; l, Lessepsian migrants; nc, not collected. 
Table 2. Cultured Sparus aurata sampled and analyzed in this study. Total number of specimens tested and number of cultured fish farm sampled in 2017 and 2018.

\begin{tabular}{ccccc}
\hline Family, Species & Origin * & 2017 & 2018 & Total \\
\hline $\begin{array}{c}\text { Sparidae } \\
\text { Sparus aurata }\end{array}$ & $\mathrm{m}, \mathrm{f}$ & 45 & 27 & 72 \\
\hline \multicolumn{4}{c}{ m, Mediterranean natives; $\mathrm{f}$, farmed species. }
\end{tabular}

\subsection{Comparison of Kidney and Liver Tissues}

In total, 251 specimens were taken from the kidneys and livers of the five fish species (four wild marine fish species and cultured S. aurata). These were analyzed and compared to determine Vibrio sp. and Mycobacterium sp. specific tissue prevalence. Only specimens tested for both tissues were included in the statistical analysis.

\subsection{Comparison of Juvenile and Adult Fish}

In total, 150 mature fish and 95 juveniles, from four fish species (only mature M. surmuletus were tested, and therefore were not tested for statistical significance), were analyzed and compared for Vibrio sp. and Mycobacterium sp. prevalence. The separation of mature and juvenile fish was determined by the total length: $N$. randalli reach sexual maturity at a total length of $\sim 110 \mathrm{~mm}$ [30]; S. aurita at a total length of $\sim 155 \mathrm{~mm}$ [31]; S. lessepsianus at a total length of $\sim 180 \mathrm{~mm}$ [32]; and S. aurata at a total length of $\sim 260 \mathrm{~mm}$ [33].

\subsection{DNA Extraction}

Extraction of total DNA from the tissues of each specimens was performed using the Wizard SV Genomic DNA Purification System kit (Promega Corporation, Madison, WI, USA) and in according to the manufacturer's specifications. Up to $20 \mathrm{mg}$ of tissue sample were placed in $275 \mu \mathrm{L}$ of manufacturer's Digestion Solution Master Mix, followed by an overnight incubation in $55^{\circ} \mathrm{C}(16-18 \mathrm{~h})$, then a $250 \mu \mathrm{L}$ of Lysis buffer was added. For purification of DNA, the lysates were transferred to the manufacturer's mini-column assembly, centrifuged for $3 \mathrm{~min}$ at $13,000 \times g$, followed by four subsequent centrifuges at $13,000 \times g$ for 1 min with $650 \mu \mathrm{L}$ wash solution. DNA was eluted using a 2-min incubation with $250 \mu \mathrm{L}$ nuclease-free water and $13,000 \times g$ centrifuge for $2 \mathrm{~min}$. The DNA concentration and quality were determined at $280 \mathrm{~nm}$ with a NanoDrop One (NanoDrop Ins., Thermo Scientific), and the extracted DNA were stored at $-20^{\circ} \mathrm{C}$ until further analysis.

\subsection{PCR Amplification}

PCR for both Vibrio sp. and Mycobacterium sp. were performed in reaction tubes preloaded with $3 \mu \mathrm{L}$ of DNA, $0.2 \mu \mathrm{L}$ of each primer, $9.1 \mu \mathrm{L}$ of ultra-pure PCR water, and $12.5 \mu \mathrm{L}$ GoTaq Green Master mix (Promega Corporation, Madison, WI, USA) on a SimpliAmp Thermal Cycler (Applied Biosystems, Foster City, CA, USA). The amplification reaction for Mycobacterium $16 \mathrm{~S}$ rRNA was subjected to 40 cycles $\left(4 \mathrm{~min}\right.$ at $95{ }^{\circ} \mathrm{C}, 30 \mathrm{~s}$ at $62{ }^{\circ} \mathrm{C}$, and $30 \mathrm{~s}$ at $72{ }^{\circ} \mathrm{C}$ ), followed by $10 \mathrm{~min}$ of extension at $72{ }^{\circ} \mathrm{C}$. Primers T39 $5^{\prime}$-GCGAACGGGTGAGTAACACG- $3^{\prime}$ and T13 5'-TGCACACAGGCCACAAGGGA-3' amplified a 924-bp segment [34]. The amplification reaction for Vibrio $16 \mathrm{~S}$ rRNA was subjected to 40 cycles $\left(4 \mathrm{~min}\right.$ at $95{ }^{\circ} \mathrm{C}, 30 \mathrm{~s}$ at $61{ }^{\circ} \mathrm{C}$, and $30 \mathrm{~s}$ at $72{ }^{\circ} \mathrm{C}$ ), followed by $10 \mathrm{~min}$ of extension at $72^{\circ} \mathrm{C}$. Primers 63f $5^{\prime}$-CAGGCCTAACACATGCAAGTC- $3^{\prime}$ and 763r 5'-GCATCTGAGTGTCAGTATCTGTCC-3' amplified a 700-bp segment [35].

\subsection{Sequencing and Phylogenetic Analysis}

Vibrio PCR (primer "63f") and Mycobacterium PCR (primer "T39") amplicons were purified by ExoSAP-IT (Affymetrix, Santa Clara, CA, USA) and sequenced by Sanger sequencing method (Hy-Labs, Rehovot, Israel). All sequences were aligned and compared to representative sequences available 
in Arb-Silva website and in GenBank by BLAST using the BioEdit Sequence Alignment Editor and MEGA10 software. Phylogenetic trees were visualized with the MEGA10 software. Robustness of nodes on the phylogeny was assessed by 1000 bootstrap replicates using Maximum Parsimony analysis. All sequences from positive samples were deposited in GenBank and accession numbers are provided in Tables S1 and S2.

\subsection{Statistical Analyses}

All statistical analyses were conducted using IBM SPSS Statistics for Windows, version 20.0 (IBM Corp., Armonk, NY, USA). Multiple logistic regression analysis was chosen to analyze the various effects on Vibrio sp. and Mycobacterium sp. prevalence. For all tests, a $p$-value of $<0.05$ was considered significant.

\section{Results}

\subsection{Vibrio sp.}

In total, 113 wild fish in 2016 and 97 in 2017 were tested for Vibrio sp. by PCR amplification (Table 3). In addition, 45 cultured fish (S. aurata) in 2017 and 27 in 2018 were also tested (Table 4). All visually inspected fish showed no external or internal alterations. Based on the sequencing results in 2016, the total prevalence of positive results for Vibrio sp. in wild fish was significantly higher compared to $2017(\mathrm{~F}=5.91, p=0.031)$. Figure 2 shows the significant effect of interaction between fish species and years $(\mathrm{F}=2.68, p=0.048)$. N. randalli, $S$. aurita, and $S$. lessepsianus exhibited a decrease in Vibrio sp. prevalence in 2017. However, M. surmuletus showed an increase in Vibrio sp. prevalence in 2017. As for the cultured fish farm, no change in prevalence was found between the years $(p>0.05)$. In 2017, the total prevalence of positive results for Vibrio sp. was $8.89 \%$, compared to 2018 when the prevalence for Vibrio sp. was 3.7\%. In total, 251 samples were collected from kidney and livers from all the five species and were tested for Vibrio sp. (Tables 5 and 6). The kidney and liver samples do not differ significantly $(p>0.05)$. From kidney samples, positive results were obtained in two samples of M. surmuletus (5.4\%), six N. randalli (9.7\%), two S. aurita (4.5\%), one S. lessepsianus (2.1\%), and two $S$. aurata (5.2\%) (Table 3). From liver samples, positive results were obtained in two samples of $M$. surmuletus (5.4\%), two S. aurita (4.5\%), and three S. aurata (4.9\%) (Table 3). No positive results were obtained in N. randalli and S. lessepsianus liver tissues. Two specimens of M. surmuletus exhibited presence of Vibrio sp. in both the liver and kidney tissues. In total, 150 mature fish and 95 juveniles from four fish species (only mature M. surmuletus were tested, and therefore this species was not included in the statistical analysis) were analyzed and compared for Vibrio sp. prevalence (Table 5, Table 6). No positive results were obtained in N. randalli and S. aurita juveniles, while positive mature fish of the same species showed a prevalence of $12.5 \%$ and $6.1 \%$, respectively. A positive result was obtained for one juvenile S. lessepsianus (25\%) and higher prevalence was found in juvenile S. aurata (7.7\% of juvenile compared to $5 \%$ of mature specimens).

The phylogenetic tree constructed from the 16S rRNA gene partial sequences (Figure 3) revealed a similarity within four different groups of Vibrio sp.: six N. randalli and two M. surmuletus segments from wild Mediterranean Sea fish shared an identical nucleotide sequence and displayed similarity to V. alginolyticus and V. parahaemolyticus (orange group, Figure 3). All these segments were detected from kidney tissues in 2016. The second group (green group, Figure 3) showed similarity to V. harveyi and contained two samples of $S$. aurita from 2016, both segments of which were from kidney and liver tissues, two 2017 M. surmuletus (liver tissue), and two cultured Mediterranean Sea fish S. aurata (one from 2017 and one from 2018). The third group contained one strain from 2016 S. lessepsianus which did not show any similarity to specific Vibrio species (yellow group, Figure 3). Three S. aurata samples from 2017 from cultured Mediterranean Sea fish also did not showed any similarity to specific Vibrio species (blue group, Figure 3). 
Table 3. Relative distribution and percentage of Vibrio in kidney and liver tissues from wild and cultured fish. Only specimens tested for both tissues were included in the statistical analyses.

\begin{tabular}{ccccc}
\hline \multirow{2}{*}{ Fish Species } & \multicolumn{2}{c}{ Kidney Tissue } & \multicolumn{2}{c}{ Liver Tissue } \\
\cline { 2 - 5 } & $\mathbf{N}$ & $\mathbf{\%}$ & $\mathbf{N}$ & $\%$ \\
\hline Mullus surmuletus & $2 / 37$ & 4.5 & $2 / 37$ & 4.5 \\
Nemipterus randalli & $6 / 62$ & 7.9 & $0 / 62$ & 0.0 \\
Sardinella aurita & $2 / 44$ & 5.4 & $2 / 44$ & 5.4 \\
Saurida lessepsianus & $1 / 47$ & 1.2 & $0 / 47$ & 0.0 \\
Sparus aurata & $2 / 61$ & 3.3 & $3 / 61$ & 9.4 \\
Total & $13 / 251$ & 2.5 & $7 / 251$ & 8.2 \\
\hline
\end{tabular}

Table 4. Relative distribution and percentage of Vibrio in juvenile and adult wild and cultured fish.

\begin{tabular}{ccccc}
\hline \multirow{2}{*}{ Fish Species } & \multicolumn{4}{c}{ Positive for Vibrio } \\
\cline { 2 - 5 } & \multicolumn{2}{c}{ Mature } & \multicolumn{2}{c}{ Juvenile } \\
\cline { 2 - 5 } & $\mathbf{N}$ & $\mathbf{\%}$ & $\mathbf{N}$ & $\mathbf{\%}$ \\
\hline Nemipterus randalli & $6 / 48$ & 12.5 & $0 / 23$ & 0 \\
Sardinella aurita & $2 / 33$ & 6.1 & $0 / 16$ & 0 \\
Saurida lessepsianus & $0 / 49$ & 0 & $1 / 4$ & 25 \\
Sparus aurata & $1 / 20$ & 5 & $4 / 52$ & 7.7 \\
Total & $9 / 150$ & 6 & $5 / 59$ & 5.3 \\
\hline
\end{tabular}

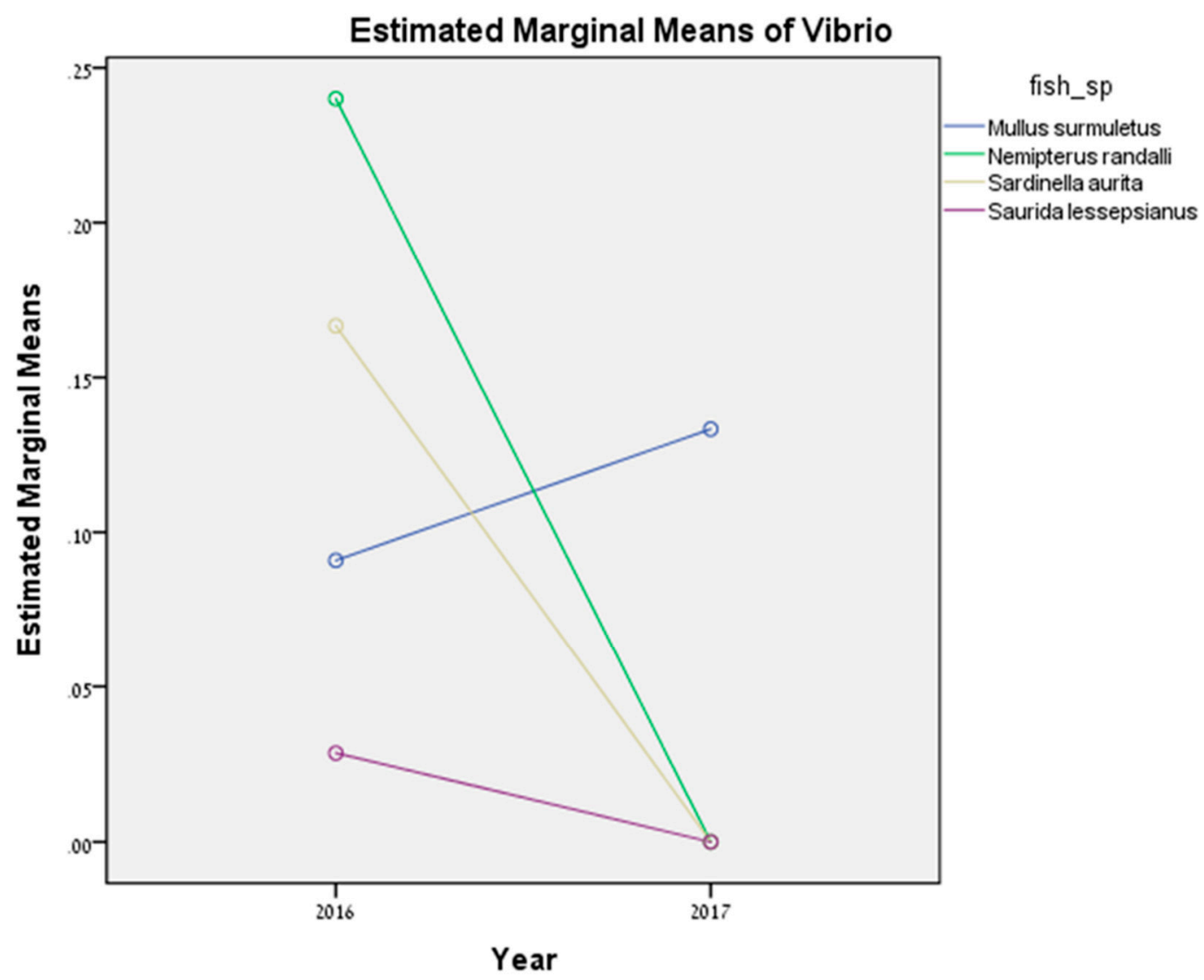

Figure 2. Vibrio sp. prevalence interaction between fish species and between years. 


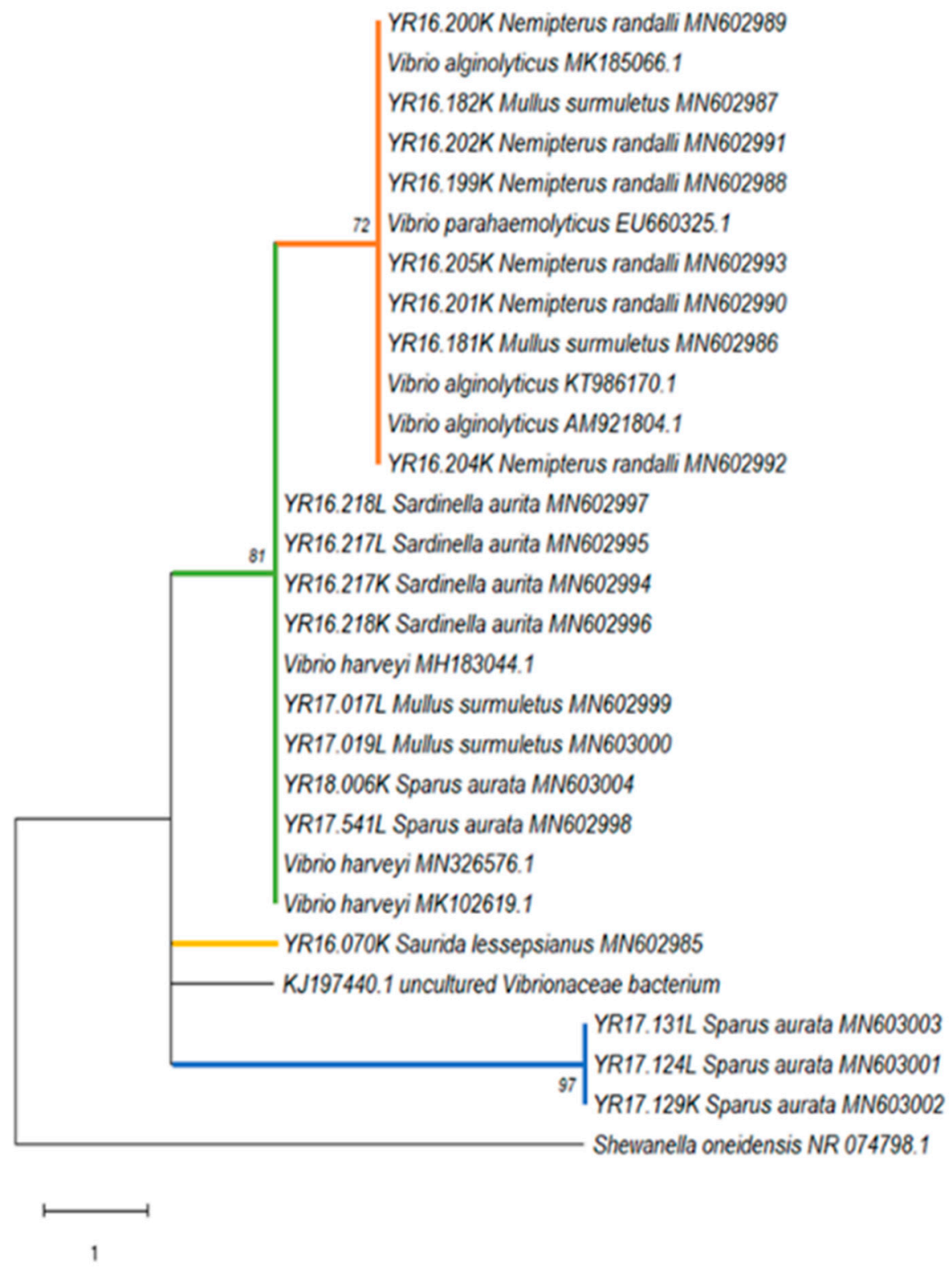

Figure 3. Vibrio sp. phylogenetic tree. Maximum Parsimony analysis phylogenetic tree of the Vibrio sp. derived from 16S rRNA gene partial sequences. The sequence name for positive samples of this study begins with YR and includes the capture year, identification number, tissue (L, liver; K, kidney), host species, and GenBank accession number. The tree was rooted by using S. oneidensis as the outgroup. Numbers on the branches indicate bootstrap proportions (1000 replicates, only values $\geq 70 \%$ are reported). Available GenBank and Arb-Silva accession numbers are shown. The scale bar represents one nucleotide substitution per site.

Table 5. Vibrio sp. prevalence in wild fish species from the Mediterranean Sea. The results are based on the PCR targeting 16S rRNA segments. Positive results refer to one or more isolated tissue.

\begin{tabular}{cccccccccc}
\hline \multirow{2}{*}{ Fish Species } & \multicolumn{4}{c}{ 2016 } & \multicolumn{2}{c}{ 2017 } & \multicolumn{2}{c}{ Total } \\
\cline { 2 - 9 } & $\mathbf{N}$ & Positive & \% Positive & N & Positive & \% Positive & N & Positive & \% Positive \\
\hline Mullus surmuletus & 22 & 2 & 9.09 & 15 & 2 & 13.33 & 37 & 4 & 10.81 \\
Sardinella aurita & 24 & 4 & 16.67 & 25 & 0 & 0.00 & 49 & 4 & 8.16 \\
Saurida lessepsianus & 38 & 1 & 2.63 & 15 & 0 & 0.00 & 53 & 1 & 1.89 \\
Nemipterus randalli & 29 & 6 & 20.69 & 42 & 0 & 0.00 & 71 & 6 & 8.45 \\
Total wild & 113 & 13 & 11.50 & 97 & 2 & 2.06 & 210 & 15 & 7.14 \\
\hline
\end{tabular}


Table 6. Vibrio prevalence in the cultured fish S. aurata from the Mediterranean Sea farmed fish. The results are based on PCR targeting 16S rRNA segments. Positive result refers to one or more isolated tissue.

\begin{tabular}{cccccccccc}
\hline \multirow{2}{*}{ Fish Species } & \multicolumn{4}{c}{2017} & \multicolumn{2}{c}{$\mathbf{2 0 1 8}$} & \multicolumn{2}{c}{ Total } \\
\cline { 2 - 10 } & $\mathbf{N}$ & Positive & \% Positive & N & Positive & \% Positive & N & Positive & \% Positive \\
\hline Sparus aurata & 45 & 4 & 8.89 & 27 & 1 & 3.70 & 72 & 5 & 6.94 \\
\hline
\end{tabular}

\subsection{Mycobacterium sp.}

In total, 113 wild fish in 2016 and 97 in 2017 were tested for Mycobacterium sp. by PCR amplification (Table 7). In addition, 45 cultured fish (S. aurata) in 2017 and 27 in 2018 were tested (Table 8). Based on the sequencing results, in the 2016 study, no positive results were recorded in wild fish, compared to 2017 when the overall prevalence for Mycobacterium sp. was 5.15\%. The only species that showed the presence of this pathogen were M. surmuletus (6.67\%) and N. randalli (9.52\%) (Table 7). According to the multiple logistic regression, no significant difference in prevalence was found over the total prevalence of Mycobacterium sp. between the years. As for the farmed fish, a significantly higher prevalence $(\mathrm{F}=9.943, p=0.002)$ was found in $2018(18.52 \%)$ compared to 2017, in which there were no positive results for Mycobacterium sp. (Table 8). In total, 251 samples were taken from the kidney and livers of each specimen from all the five fish species and tested for Mycobacterium sp. (Table 9). A significantly higher prevalence was found in kidney samples compared to liver tissues $(\mathrm{F}=2.518$, $p=0.041$ ). From the kidney samples, positive results were obtained in one specimen of M. surmuletus $(2.7 \%)$, four N. randalli (6.5\%), and two S. aurata $(3.3 \%)$. From liver samples, positive results were only obtained in two N. randalli (3.2\%) (Table 10). No positive results were obtained in S. aurita (Table 2) and S. lessepsianus tissues. One specimen of N. randalli exhibited presence of Mycobacterium sp. in both the liver and kidney tissues. In total, 150 mature fish and 95 juveniles from four fish species (only mature M. surmuletus were tested and thus were not included in the statistical analyses) were analyzed and compared to ascertain Mycobacterium sp. prevalence (Table 10). No positive results were obtained in both mature and juvenile S. aurita and S. lessepsianus. Higher prevalence was observed in mature N. randalli and S. aurata compared to their juvenile counterparts. There was no significant difference $(p>0.05)$ in total prevalence of Mycobacterium sp. between the mature and the juvenile. The phylogenetic analysis of Mycobacterium segments revealed similarity across three different groups of Mycobacterium (Figure 4): three 2017 N. randalli and one M. surmuletus segments from wild Mediterranean Sea fish shared an identical nucleotide sequence (YR17.015K differed by one nucleotide) and showed similarity to M. peregrinum (orange group, Figure 4). N. randalli YR17.001L (green group, Figure 4) showed similarity to $M$. neoaurum, only differing from the orange group by nine nucleotides. All five segments from the 2018 fish farmed S. aurata were identical to each other, were similar to M. marinum (blue group, Figure 4), and differed from the orange group by 21 nucleotides.

Table 7. Mycobacterium prevalence in wild fish species from the Mediterranean Sea. The results are based on PCR targeting 16S rRNA segments.

\begin{tabular}{cccccccccc}
\hline \multirow{2}{*}{ Fish Species } & \multicolumn{4}{c}{$\mathbf{2 0 1 6}$} & \multicolumn{2}{c}{$\mathbf{2 0 1 7}$} & \multicolumn{2}{c}{ Total } \\
\cline { 2 - 10 } & $\mathbf{N}$ & Positive & \% Positive & $\mathbf{N}$ & Positive & \% Positive & N & Positive & \% Positive \\
\hline Mullus surmuletus & 22 & 0 & 0 & 15 & 1 & 6.67 & 37 & 1 & 2.7 \\
\hline Sardinella aurita & 24 & 0 & 0 & 25 & 0 & 0 & 49 & 0 & 0 \\
\hline Saurida lessepsianus & 38 & 0 & 0 & 15 & 0 & 0 & 53 & 0 & 0 \\
\hline Nemipterus randalli & 29 & 0 & 0 & 42 & 4 & 9.52 & 71 & 4 & 5.63 \\
\hline Total wild & 113 & 0 & 0 & 97 & 5 & 5.15 & 210 & 5 & 2.38 \\
\hline
\end{tabular}


Table 8. Mycobacterium prevalence in the cultured fish S. aurata from the Mediterranean Sea fish farm. The results are based on PCR targeting 16S rRNA segments.

\begin{tabular}{cccccccccc}
\hline \multirow{2}{*}{ Fish Species } & \multicolumn{4}{c}{2017} & \multicolumn{2}{c}{2018} & \multicolumn{2}{c}{ Total } \\
\cline { 2 - 11 } & N & Positive & \% Positive & N & Positive & \% Positive & N & Positive & \% Positive \\
\hline Sparus aurata & 45 & 0 & 0 & 27 & 5 & 18.52 & 72 & 5 & 6.94 \\
\hline
\end{tabular}

Table 9. Relative distribution and percentage of Mycobacterium sp. in kidney and liver tissues from wild and cultured fish. Only specimens tested for both tissues were included in the statistical analysis.

\begin{tabular}{ccccc}
\hline \multirow{2}{*}{ Fish Species } & \multicolumn{4}{c}{ Positive for Mycobacterium } \\
\cline { 2 - 5 } & $\mathbf{N}$ & $\%$ & $\mathbf{N}$ & Liver Tissue \\
\cline { 2 - 5 } & $1 / 37$ & 2.7 & $0 / 37$ & 0 \\
\hline Mullus surmuletus & $4 / 62$ & 6.5 & $2 / 62$ & 3.2 \\
\hline Nemipterus randalli & $0 / 44$ & 0 & $0 / 44$ & 0 \\
\hline Sardinella aurita & $0 / 47$ & 0 & $0 / 47$ & 0 \\
\hline Saurida lessepsianus & $2 / 61$ & 3.3 & $0 / 61$ & 0 \\
\hline Sparus aurata & $7 / 251$ & 2.8 & $2 / 251$ & 0.8 \\
\hline Total & &
\end{tabular}

Table 10. Relative distribution and percentage of Mycobacterium in juvenile and adult wild and cultured fish.

\begin{tabular}{ccccc}
\hline \multirow{2}{*}{ Fish Species } & \multicolumn{3}{c}{ Positive for Mycobacterium } \\
\cline { 2 - 5 } & $\mathbf{2}$ Mature & Juvenile \\
\cline { 2 - 5 } & $\mathbf{N}$ & $\%$ & $\mathbf{N}$ & $\%$ \\
\hline Nemipterus randalli & $5 / 48$ & 10.4 & $0 / 23$ & 0 \\
Sardinella aurita & $0 / 33$ & 0 & $0 / 16$ & 0 \\
Saurida lessepsianus & $0 / 49$ & 0 & $0 / 4$ & 0 \\
Sparus aurata & $2 / 20$ & 10 & $3 / 52$ & 5.8 \\
Total & $7 / 150$ & 4.7 & $3 / 95$ & 3.2 \\
\hline
\end{tabular}

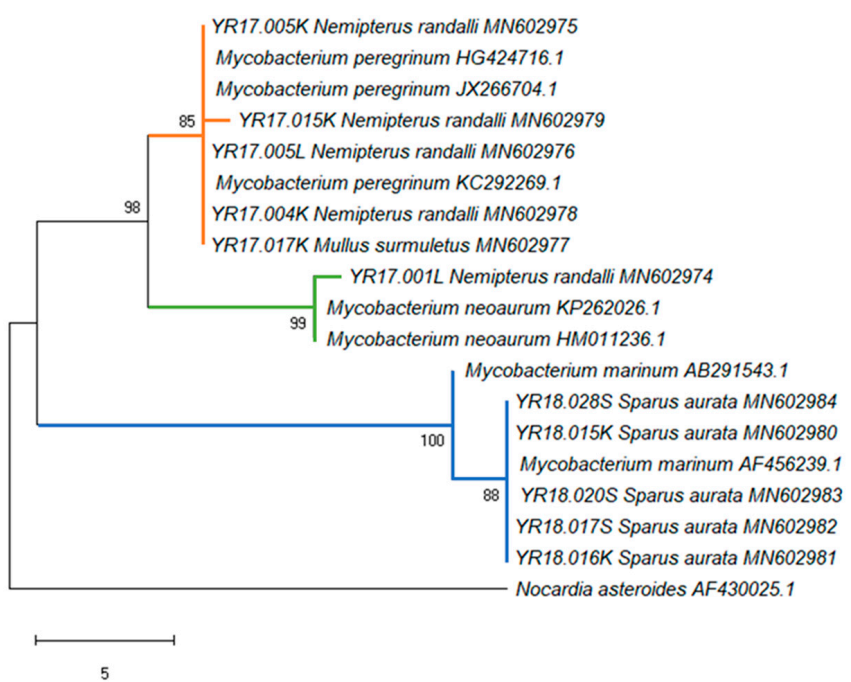

Figure 4. Mycobacterium sp. phylogenetic tree. Phylogenetic tree output from the Maximum Parsimony analysis of the Mycobacterium sp. derived from 16S rRNA gene partial sequences. The sequence name for positive samples of this study begins with $\mathrm{YR}$ and includes the capture year, identification number, tissue (L, liver; K, kidney; S, spleen), host species, and GenBank accession number. The tree was rooted by using $N$. asteroides as outgroup. Numbers on the branches indicate bootstrap proportions (1000 replicates, only values $\geq 70 \%$ are reported). Available GenBank and Arb-Silva accession numbers are shown. The scale bar represents five nucleotide substitution per site. 


\section{Discussion}

Vibrio sp. and Mycobacterium sp. are widespread in nature, especially in the marine environment. Fish infected by these bacteria could be a source of zoonotic risk for human health [26], and are known to cause infections in humans with different degrees of severity, especially in immunocompromised individuals [22,36]. Although Vibrio sp. and Mycobacterium sp. have been detected and studied in many fish species around the world, including various wild marine fish species [21,37-41], at the time of writing, this is the first study to identify Vibrio sp. in the Lessepsian migrant species Saurida lessepsianus and the endemic Mediterranean fish Sardinella aurita.

In this study, the presence of two important aquatic bacteria were investigated in four marine wild fish and one cultured farm fish in the eastern Mediterranean Sea. Both pathogens were detected in indigenous and Lessepsian species, and their prevalence varied greatly between fish species. In both pathogens, there were no statistically significant differences between the different wild species. However, the overall prevalence of Vibrio sp. was significantly higher in 2016 compared to 2017. Vibrio species are omnipresent and widely distributed in aquatic environments all over the world [42]. The occurrence of Vibrio sp. In fish, is commonly associated with elevated temperature, especially in temperate climes. Generally, Vibrio species are detected in summer but are less common in winter, whereas the variations of Vibrio sp. population size are lower in tropical and subtropical waters [43]. Reports have shown a significant association between rising seawater temperature and an increase in the number of Vibrio sp. infections, suggesting that global warming could be a factor in the emergence of vibriosis in temperate areas, due to its influence on resident bacterial communities [43]. In 2016, during a continuous survey, most of the positive samples were detected in the summer period, which can explain the higher prevalence of Vibrio sp. in 2016. However, most of the surveys in 2017 were between October and December, and the prevalence was lower. Within the cultured fish species, in 2018, the prevalence for Mycobacterium sp. in S. aurata was significantly higher compared to 2017, where no infection was detected at all. Due to logistical difficulties in field sampling (a seasonal ban on fishing vessels), we could not sample each season more than once for appropriate comparison. Thus, we cannot definitely determine if the prevalence of Vibrio sp. is related to temporal changes in exposure or due to temperature shifts. Hence, this is a limitation of this study. The total prevalence for both pathogens was higher in the Lessepsian fish N. randalli and in the indigenous M. surmuletus, with no reported clinical signs. High prevalence in an asymptomatic fish may indicate they can serve as carriers and horizontally infect other susceptible species living in proximity [44]. N. randalli is an invasive species, first reported in the Mediterranean in 2005 [45], and has become a dominant fish species in the Israeli ichthyofauna within the past five years [46]; the reasons for its successful establishment are unknown [47]. Although Vibrio sp. and Mycobacterium sp. can be isolated from different organs (e.g., spleen and liver), it has been suggested that these pathogens have an affinity for, or are better detected, in kidney tissue $[48,49]$. This is in agreement with our results, where the prevalence for both pathogens in kidney was higher than in liver tissues in most of the examined fish species. In addition, the comparison of Vibrio sp. and Mycobacterium sp. prevalence in juvenile and adult fish was examined in four out of the five fish species (only mature M. surmuletus were detected in this study and therefore were not included in the statistical analysis). In the wild fish, the highest prevalence was detected in adult-stage specimens. However, as for the cultured fish S. aurata, positive results were obtained in both adult and juvenile specimens. It seems that at least the fish species tested in this study in different life stages are similarly susceptible for infection of Vibrio sp. and Mycobacterium sp. [50].

Phylogenetic analyses, based on the 16S rRNA gene sequences, revealed that all detected Vibrio strains were divided into four different genogroups of Vibrio sp., with an overlap in one group between the wild and the cultured species. This may suggest a spontaneous transmission between the wild and the farm fish. The first group showed high similarity to V. parahaemolyticus and V. alginolyticus. According to Montieri et al. [35], these two Vibrio species share nearly identical sequences in $16 \mathrm{~S}$ rRNA gene (99.8\% identity), and therefore this gene is inadequate for the separation between the two species. The second group showed high similarity to $V$. harveyi. These species are known to be 
dangerous to humans, marine fish, and invertebrates and they can cause various diseases including vasculitis, gastroenteritis, septicemia, and skin infections [51-53]. The third group contained only one strain that belonged to the Lessepsian fish S. lessepsianus, which showed similarity to uncultured Vibrionaceae bacterium isolated from pinfish (Lagodon rhomboids) [54], with a 95\% homology. To the best of our knowledge, there were no records in the literature about the presence of Vibrio sp. in this fish species. A possible explanation is that there is species-specific adaptation of some Vibrio species [55] and, therefore, this specific genotype might be a new Vibrio genotype that is specific for S. lessepsianus and possibly other marine fish. Further isolation and characterization of Vibrio species is needed from this fish to understand its full genetic properties. In addition, the fourth group contained three identical strains all belonging to the cultured S. aurata from 2017 without any similar references. It seems that this group has a unique insertion of 11 nucleotides which is common in $16 \mathrm{~S}$ rRNA gene sequences, where insertion-deletion events are frequent and result in length differences among homologous sequences [56]. The phylogenetic analysis of Mycobacterium sp. reveals a clear separation between the wild and the cultured species: the wild species were positive across two main groups of Mycobacterium sp. (with high similarity to M. peregrinum and M. neoaurum), while positive samples of the cultured fish S. aurata were similar to M. marinum. All these Mycobacterium sp. are known as pathogenic species. Both M. peregrinum and M. neoaurum are fast growing mycobacteria that can cause bloodstream infections in immunocompromised hosts, and, unlike other NTM species [57]. M. marinum is a recognized fish pathogen that can also infect endothermic organisms, including humans. In human infections, M. marinum gains access to the body through skin abrasions and generally produces superficial and self-limiting lesions which involve the cooler parts of the body such as hands, forearms, elbows, and knees [58,59]. Although M. marinum is a well-recognized pathogen of fish, M. peregrinum has only recently been associated with diseases in fish [60]. Even though mycobacteriosis cases have been reported previously in wild and cultured fish species $[39,61]$, in this study, we documented Mycobacteria in N. randalli for the first time. Over the last few decades, the $16 \mathrm{~S}$ rRNA gene has emerged as a good standard for determining phylogenetic relationships of bacteria [62]. By using PCR amplification and direct sequencing of 16S rRNA products, Knibb et al. [63] identified M. marinum directly from infected fish. This has allowed both proper taxonomic assignment and has opened the way to molecular epidemiologic analysis at the same time. However, even though this gene is still considered a key standard for bacterial identification $[64,65]$, as more sequence information has accumulated over time, it has become evident that the resolution power of 16S rRNA sequences alone is often insufficient when closely related organisms are compared [66]. Furthermore, Palys et al. [66] suggested that protein-encoding genes may be more discriminative than those encoding rRNA, while the analysis of two or more unlinked loci would prevent bacterial misclassification due to possible homologous recombination with other taxa. Therefore, further molecular analyses are needed to understand the epidemiology and pathogenicity of the Vibrio sp. and Mycobacterium sp. identified in this study, both on fish and humans.

In the summer of 2018, there was an outbreak of M. marinum in three out of the seven fish cages examined. The death rate ranged $5.7-13.5 \%$, and some of the fish that survived showed clinical signs for the pathogen or no signs at all. M. marinum was isolated from the kidney and spleen of both juvenile and adult fish. There was no evidence of the disease in 2017. A possible explanation is that in 2017 each cage was populated with $\sim 350,000$ fish, in contrast to 2018 where each cage was populated with $\sim 470,000$ fish. These conditions might have led to the disease outbreaks. As farmed fish are monitored regularly, they can be used as sentinels to evaluate pathogen exposure in the aquatic environment. However, this approach has utility only if farmed fish are susceptible to the pathogen and enter the marine environment free of the pathogen of interest. In addition, occurrence of disease in farmed fish populations does not necessarily imply occurrence of the same disease in wild populations. It is difficult to evaluate the health effect of escapees on the ecosystem without taking into consideration the qualitative aspects of wild fish assemblages around farms. Cross-contagion between farmed and wild fish species with shared pathogens may occur [67] either through movements of individual fish or 
through species-specific migrations [68,69]. Connection among farms and other marine areas of interest through wild fish movements have been demonstrated both in Norwegian [70] and in Mediterranean fish farms [67]. Unlike parasitic pathogens, bacteria seem to exhibit higher potential to spread between wild and farmed fish. This is likely because the ecological barriers that exist for parasite transfer do not represent a great obstacle for bacteria [13]. Firstly, bacteria are almost always present on the skin surface of fish. Secondly, bacterial diseases are usually treated by non-professional staff at the farms, and consequently involve increased risk of developing resistance and more pathogenic strains. Finally, bacteria are often generalists and do not need wild conspecifics to spread from farmed fish [13]. There is a potential risk of pathogen transmission through movements of escaped and wild fish in Mediterranean fish farming areas, but actual transmission has been documented only in a handful of cases [71]. Due to technical or operational malfunctions, infected farmed fish may escape and, in theory, spread pathogens to other cages/farms and wild fish as well. Furthermore, infected wild fish might also transfer pathogens to the farmed fish [72]. This co-infection process leads to a large variety of shared pathogens among wild and farmed fish, while the various pathways of pathogen transmission increase the potential for infection and render epidemiological risk management difficult [71]. Further research on molecular mechanisms of disease transmission in aquaculture and marine environments, as well more holistic analyses of pathogenic events in the Mediterranean Sea, are needed to clarify the potential of transmission of pathogens from aquaculture to the marine ecosystems.

\section{Conclusions}

As Mediterranean mariculture is expected to increase in the near future, bacteria such as Vibrio sp. and Mycobacterium sp. remain important infectious pathogens of wild and cultured finfish and should be extensively studied and investigated. Vibrio sp. and Mycobacterium sp. prevalence in asymptomatic fish may indicate that they can serve as carriers and infect other susceptible species. As many Vibrio sp. and Mycobacterium sp. infect fish and humans, the potential for zoonotic infection presents an additional challenge. Although these diseases have been studied in fish for over a century, basic questions about their pathobiology, including transmission and host defense mechanisms remain unknown. Additionally, effective prophylaxis, control measures, and non-lethal diagnostics require research and development. However, with the advent of modern molecular detection methods, epidemiological techniques, and vaccinology, considerable potential exists for the improvement of our understanding and control of those diseases in the future.

Supplementary Materials: The following are available online at http://www.mdpi.com/2076-2607/8/6/863/s1. Table S1: List of Mycobacterium sp. positive results with GenBank accession numbers, Table S2: List of Vibrio sp. positive results with GenBank accession numbers.

Author Contributions: Conceptualization, D.M., D.T., and A.P.S.; software, Y.R. and R.B.; validation, D.M.; formal analysis, Y.R.; investigation, Y.R. and D.M.; data curation, Y.R., R.B., and D.M.; writing-original draft preparation, Y.R.; writing-review and editing, D.M. and N.D.; and supervision, S.C.K.L. All authors have read and agreed to the published version of the manuscript.

Funding: This study was financially supported by the Kahn Foundation and by the Hong Kong Branch of Southern Marine Science and Engineering Guangdong Laboratory (Guangzhou) (SMSEGL20SC02).

Conflicts of Interest: The authors declare no conflict of interest. The funders had no role in the design of the study; in the collection, analyses, or interpretation of data; in the writing of the manuscript; or in the decision to publish the results.

\section{References}

1. Harvell, C.D.; Kim, K.; Burkholder, J.M.; Grimes, D.J.; Hoffmann, E.E.; Lipp, E.K.; Osterhaus, A.D.M.E.; Overstreet, R.M.; Porter, J.W.; Smith, G.W.; et al. Marine Diseases-Climate Links and Anthropogenic Factors. Science 1999, 580, 1505-1510. [CrossRef]

2. Harvell, C.D.; Mitchell, C.E.; Ward, J.R.; Altizer, S.; Dobson, A.P.; Ostfeld, R.S.; Samuel, M.D. Climate Warming and Disease Risks for Terrestrial and Marine Biota. Science 2002, 296, 2158-2162. [CrossRef] 
3. Gratzek, J.B.; Reinert, R. Physiological responses of experimental fish to stressful conditions. Natl. Cancer Inst. Monogr. 1984, 65, 187-188.

4. Coll, M.; Piroddi, C.; Steenbeek, J.; Kaschner, K.; Lasram, F.B.R.; Aguzzi, J.; Ballesteros, E.; Bianchi, C.N.; Corbera, J.; Dailianis, T.; et al. The Biodiversity of the Mediterranean Sea: Estimates, Patterns, and Threats. PLOS ONE 2010, 5, e11842. [CrossRef]

5. Lejeusne, C.; Chevaldonné, P.; Pergent-Martini, C.; Boudouresque, C.F.; Perez, T. Climate change effects on a miniature ocean: The highly diverse, highly impacted Mediterranean Sea. Trends Ecol. Evol. 2010, 25, 250-260. [CrossRef]

6. FAO. The State of Fisheries and Aquaculture in the World; FAO: Rome, Italy, 2018; Volume 100, pp. 332-333.

7. Holmlund, C.M.; Hammer, M. Ecosystem services generated by fish populations. Ecol. Econ. 1999, 29, 253-268. [CrossRef]

8. Ward, J.R.; Lafferty, K.D. The elusive baseline of marine disease: Are diseases in ocean ecosystems increasing? PLoS Boil. 2004, 2, E120. [CrossRef]

9. FAO. The State of World Fisheries and Aquaculture 2016. Contributing to Food Security and Nutrition for All; FAO: Rome, Italy, 2016; Volume 200.

10. Fernandez-Gonzalez, V.; Sanchez-Jerez, P. Fouling assemblages associated with off-coast aquaculture facilities: An overall assessment of the Mediterranean Sea. Mediterr. Mar. Sci. 2017, 18, 87. [CrossRef]

11. Davidovich, N.; Pretto, T.; Sharon, G.; Zilberg, D.; Blum, S.E.; Baider, Z.; Edery, N.; Morick, D.; Grossman, R.; Kaidar-Shwartz, H.; et al. Cutaneous appearance of mycobacteriosis caused by Mycobacterium marinum, affecting gilthead seabream (Sparus aurata) cultured in recirculating aquaculture systems. Aquaculture 2020, 735507. [CrossRef]

12. FAO. Global Aquaculture Production 2017. Available online: http://www.fao.org/fishe\%0Ary/statistics/ global-production/en (accessed on 10 April 2020).

13. Lopez, P.A.; Sanchez-Jerez, P.; Bayle-Sempere, J.T.; Uglem, I.; Mladineo, I. Reared fish, farmed escapees and wild fish stocks-A triangle of pathogen transmission of concern to Mediterranean aquaculture management. Aquac. Environ. Interact. 2013, 3, 153-161. [CrossRef]

14. Johansen, L.H.; Jensen, I.; Mikkelsen, H.; Bjørn, P.A.; Jansen, P.A.; Bergh, O. Disease interaction and pathogens exchange between wild and farmed fish populations with special reference to Norway. Aquaculture 2011, 315, 167-186. [CrossRef]

15. Lafferty, K.D.; Harvell, C.D.; Conrad, J.M.; Friedman, C.S.; Kent, M.L.; Kuris, A.M.; Powell, E.N.; Rondeau, D.; Saksida, S.M. Infectious Diseases Affect Marine Fisheries and Aquaculture Economics. Annu. Rev. Mar. Sci. 2015, 7, 471-496. [CrossRef] [PubMed]

16. Wade, J. Pathogen exchange between wild and farmed finfish: Evidence to assess pathogen source and factors associated with clinical disease occurrence. Bull. Aquac. Assoc. Can. 2014, 111, 35.

17. Gauthier, D.T.; Rhodes, M.W. Mycobacteriosis in fishes: A review. Vet. J. 2009, 180, 33-47. [CrossRef]

18. Haenen, O.L.M.; Evans, J.J.; Berthe, F. Bacterial infections from aquatic species: Potential for and prevention of contact zoonoses. OIE Rev. Sci. Tech. 2013, 32, 497-507. [CrossRef]

19. García-Rosado, E.; Cano, I.; Martín-Antonio, B.; Labella, A.; Manchado, M.; Alonso, M.C.; Castro, D.; Borrego, J.J. Co-occurrence of viral and bacterial pathogens in disease outbreaks affecting newly cultured sparid fish. Int. Microbiol. 2007, 10, 193-199.

20. Reen, F.J.; Almagro-Moreno, S.; Ussery, D.; Boyd, E.F. The genomic code: Inferring Vibrionaceae niche specialization. Nat. Rev. Microbiol. 2006, 4, 697-704. [CrossRef]

21. Kokashvili, T.; Whitehouse, C.A.; Tskhvediani, A.; Grim, C.J.; Elbakidze, T.; Mitaishvili, N.; Janelidze, N.; Jaiani, E.; Haley, B.J.; Lashkhi, N.; et al. Occurrence and Diversity of Clinically Important Vibrio species in the Aquatic Environment of Georgia. Front. Public Health 2015, 3, 1-12. [CrossRef]

22. Ceoccarelli, D.; Colwell, R.R. Vibrio ecology, pathogenesis, and evolution. Front. Microbiol. 2014, 5, 1-2.

23. Haldar, S.; Neogi, S.B.; Kogure, K.; Chatterjee, S.; Chowdhury, N.; Hinenoya, A.; Askura, M.; Yamasaki, S. Development of a haemolysin gene-based multiplex PCR for simultaneous detection of Vibrio campbellii, Vibrio harveyi and Vibrio parahaemolyticus. Lett. Appl. Microbiol. 2010, 50, 146-152. [CrossRef]

24. Noga, E.J. Fish Disease. In Diagnosis and Treatment, 2nd ed.; Wiley-Blackwell: Mosby St. Louis, MO, USA, 2010; pp. 193-208. 
25. Novotny, L.; Halouzka, R.; Matlova, L.; Vavra, O.; Bartosova, L.; Slany, M.; Pavlik, I. Morphology and distribution of granulomatous inflammation in freshwater ornamental fish infected with mycobacteria. J. Fish. Dis. 2010, 33, 947-955. [CrossRef] [PubMed]

26. Tortoli, E. Microbiological features and clinical relevance of new species of the genus Mycobacterium. Clin. Microbiol. Rev. 2014, 27, 727-752. [CrossRef] [PubMed]

27. Francis-Floyd, R. Mycobacterial Infections of Fish. SRAC Publ. 2011, 4706, 1-12.

28. Toranzo, A.E.; Magariños, B.; Romalde, J.L. A review of the main bacterial fish diseases in mariculture systems. Aquaculture 2005, 246, 37-61. [CrossRef]

29. Yanong, R.P.E. Necropsy techniques for fish. Semin. Avian Exot. Pet. Med. 2003, 12, 89-105. [CrossRef]

30. Demirci, S.; Demirci, A.; Simsek, E. Spawning season and size at maturity of a migrated fish, Randall's threadfin bream in Iskenderun bay, northeastern Mediterranean, Turkey. Fresenius. Environ. Bull. 2018, 27, 503-507.

31. Tsikliras, A.C.; Antonopoulou, E. Reproductive biology of round sardinella (Sardinella aurita) in the north-eastern Mediterranean. Sci. Mar. 2006, 70, 281-290. [CrossRef]

32. El-Halfawy, M.M.; Amin, A.M.; Ramadan, A.M. Growth and Reproduction of Female Brushtooth Lizardfish Saurida undosquamis (Richardson) from the Gulf of Suez, Egypt. E.U. J. Fish. Aqu. Sci. 2007, 24, 143-148.

33. Yilmaz, E.; Ismet, B.; Cetin, S.D.; Aytug, O.H.; Ozgur, Y. Growth and reproduction studies on gilthead seabream (Sparus aurata) in Beimelek Lagoon, Turkey. Iran. J. Fish. Sci. 2009, 8, 103-114.

34. Talaat, A.M.; Reimschuessel, R.; Trucksis, M. Identification of mycobacteria infecting fish to the species level using polymerase chain reaction and restriction enzyme analysis. Vet. Microbiol 1997, 58, 229-237. [CrossRef]

35. Montiert, S.; Suffredini, E.; Ciccozzi, M.; Croci, L. Phylogenetic and evolutionary analysis of Vibrio parahaemolyticus and Vibrio alginolyticus isolates based on toxR gene sequence. New Microbiol. 2010, 33, 359-372.

36. Bercovier, H.; Vincent, V. Mycobacterial infections in domestic and wild animals due to Mycobacterium marinum, M. fortuitum, M. chelonae, M. porcinum, M. farcinogenes, M. smegmatis, M. scrofulaceum, M. Xenopi, M. Kansasii, M. simiae and M. genavense. OIE Rev. Sci. Tech. 2001, 20, 265-290. [CrossRef] [PubMed]

37. Diamant, A.; Banet, A.; Ucko, M.; Colorni, A.; Knibb, W.; Kvitt, H. Mycobacteriosis in wild rabbitfish Siganus rivulatus associated with cage farming in the Gulf of Eilat, Red Sea. Dis. Aquat. Organ. 2000, 39, 211-219. [CrossRef] [PubMed]

38. Ucko, M.; Colorni, A.; Kvitt, H.; Diamant, A.; Zlotkin, A.; Knibb, W.R. Strain variation in Mycobacterium marinum fish isolates. Appl. Environ. Microbiol. 2002, 68, 211-219. [CrossRef] [PubMed]

39. Sevim, P.; Ozer, S.; Rad, F. First isolation of Mycobacterium spp. in Mullus spp. in Turkey. Iran. J. Vet. Res. 2015, 16, 144-149.

40. Senderovich, Y.; Izhaki, I.; Halpern, M. Fish as reservoirs and vectors of Vibrio cholerae. PLoS ONE 2010, 5, e8607. [CrossRef]

41. Bluford, J.; Gauthier, D.; Colasanto, M.; Rhodes, M.; Vogelbein, W.; Haines, A. Identification of virulence genes in Vibrio spp. isolates from the 2009 Bermuda reef fish mortality event. J. Fish. Dis. 2017, 40, 597-600. [CrossRef]

42. Rivera, I.N.G.; Urakawa, H. The Biology of Vibrios: Aquatic Environment; ASM Press: Washington, DC, USA, 2006; pp. 175-189.

43. Huehn, S.; Eichhorn, C.; Urmersbach, S.; Breidenbach, J.; Bechlars, S.; Bier, N.; Altera, T.; Bartelte, E.; Frankc, C.; Oberheitmannf, B.; et al. Pathogenic vibrios in environmental, seafood and clinical sources in Germany. Int. J. Med. Microbiol. 2014, 304, 843-850. [CrossRef]

44. Castric, J.; Thiéry, R.; Jeffroy, J.; De Kinkelin, P.; Raymond, J.C. Sea bream Sparus aurata, an asymptomatic contagious fish host for nodavirus. Dis. Aquat. Organ. 2001, 47, 33-38. [CrossRef]

45. Golani, D.; Sonin, O. The Japanese threadfin bream Nemipterus japonicus, a new Indo-Pacific fish in the Mediterranean Sea. J. Fish. Biol. 2006, 68, 940-943. [CrossRef]

46. Stern, N.; Levitt, Y.; Galil, B.S.; Diamant, A.; Yokeş, M.B.; Goren, M. Distribution and population structure of the alien Indo-Pacific Randall's threadfin bream Nemipterus randalli in the eastern Mediterranean Sea. J. Fish. Biol. 2014, 85, 394-406. [CrossRef] [PubMed]

47. Edelist, D. Fishery Management and Marine Invasion in Israel. Ph.D. Thesis, University of Haifa, Haifa, Israel, 2013; pp. 1-200. 
48. Yu, A.S.L.; Chertow, G.M.; Luyckx, V.; Marsden, P.A.; Skorecki, K.; Taal, M.W. Brenner and Rector's the Kidney; Elsevier Health Sciences: Maryland, MO, USA, 2015; pp. 1-2784.

49. Hammarén, M. Zebrafish Model. for Studying the Disease Spectrum of Tuberculosis. Ph.D. Thesis, University of Tampere, Tampere, Finland, December 2017.

50. Colorni, A.; Diamant, A. Infectious diseases of warmwater fish in marine and brackish waters. In Diseases and Disorders of Finfish in Cage Culture, 2nd ed.; Woo, P., Bruno, D., et al., Eds.; CABI Publishing: Wallingford, Oxfordshire, UK, 2014; pp. 155-192.

51. Bej, A.K.; Patterson, D.P.; Brasher, C.W.; Vickery, M.C.L.; Jones, D.D.; Kaysner, C.A. Detection of total and hemolysin-producing Vibrio parahaemolyticus in shellfish using multiplex PCR amplification of $\mathrm{tl}$, $\mathrm{tdh}$ and trh. J. Microbiol. Methods 1999, 36, 215-225. [CrossRef]

52. Austin, B.; Zhang, X.H. Vibrio Harveyi: A significant pathogen of marine vertebrates and invertebrates. Lett. Appl. Microbiol. 2006, 43, 119-124. [CrossRef]

53. Osunla, C.A.; Okoh, A.I. Vibrio Pathogens: A Public Health Concern in Rural Water Resources in Sub-Saharan Africa. Int. J. Environ. Res. Public Health 2017, 14, 1188. [CrossRef]

54. Givens, C.; Ransom, B.; Bano, N.; Hollibaugh, J. Comparison of the gut microbiomes of 12 bony fish and 3 shark species. Mar. Ecol Prog Ser. 2015, 518, 209-223. [CrossRef]

55. Nishiguchi, M.K.; Nair, V.S. Evolution of symbiosis in the Vibrionaceae: A combined approach using molecules and physiology. Int. J. Syst. Evol. Microbiol. 2003, 53, 2019-2026. [CrossRef]

56. Urbanczyk, H.; Ast, J.C.; Higgins, M.J.; Carson, J.; Dunlap, P.V. Reclassification of Vibrio fischeri, Vibrio logei, Vibrio salmonicida and Vibrio wodanis as Aliivibrio fischeri gen. nov., comb. nov., Aliivibrio logei comb. nov., Aliivibrio salmonicida comb. nov. and Aliivibrio wodanis comb. nov. Int. J. Syst. Evol. Microbiol. 2007, 57, 2823-2829. [CrossRef]

57. Kim, C.K.; Choi, S.I.; Jeon, B.R.; Lee, Y.W.; Lee, Y.K.; Shin, H.B. Pulmonary infection caused by Mycobacterium neoaurum: The first case in Korea. Ann. Lab. Med. 2014, 34, 243-246. [CrossRef]

58. Ucko, M.; Colorni, A. Mycobacterium marinum Infections in Fish and Humans in Israel. J. Clin. Microbiol. 2005, 43, 892-895. [CrossRef]

59. Todorova, T.T.; Kaludova, V.; Tsankova, G.; Ermenlieva, N. Pulmonary Infection Caused by Mycobacterium Peregrinum- A Case Report. J. IMAB - Annu. Proc. 2015, 21, 1000-1002. [CrossRef]

60. Kent, M.L.; Whipps, C.M.; Matthews, J.L.; Florio, D.; Watral, V.; Bishop-Stewart, J.K.; Poorta, M.; Bermudeza, L. Mycobacteriosis in zebrafish (Danio rerio) research facilities. Comp. Biochem. Physiol. Part C Toxicol. Pharmacol. 2004, 138, 383-390. [CrossRef] [PubMed]

61. Colorni, A. A systemic mycobacteriosis in the European sea bass Dicentrarchus labrax cultured in Eilat (Red Sea). Isr. J. Aquac.-Bamidgeh. 1992, 44, 75-81.

62. Woese, C.R. Bacterial evolution. Microbiol. Rev. 1987, 51, 221-271. [CrossRef] [PubMed]

63. Knibb, W.; Colorni, A.; Ankaoua, M.; Lindell, D.; Diamant, A.; Gordin, H. Detection and identification of a pathogenic marine Mycobacterium from the European seabass Dicentrarchus labrax using polymerase chain reaction and direct sequencing of 16S rDNA sequences. Mol. Mar. Biol. Biotechnol. 1993, 2, 225-232. [PubMed]

64. Gillman, L.M.; Gunton, J.; Turenne, C.Y.; Wolfe, J.; Kabani, A.M. Identification of Mycobacterium species by multiple-fluorescence PCR-single-strand conformation polymorphism analysis of the 16S rRNA gene.s. J. Clin. Microbiol. 2001, 39, 3085-3091. [CrossRef]

65. Turenne, C.Y.; Tschetter, L.; Wolfe, J.; Kabani, A. Necessity of quality-controlled 16S rRNA gene sequence databases: Identifying nontuberculous Mycobacterium species. J. Clin. Microbiol. 2001, 39, 3637-3648. [CrossRef]

66. Palys, T.; Nakamura, L.K.; Cohen, F.M. Discovery and Classification of Ecological Diversity in the Bacterial World: The Role of DNA Sequence Data. Int. J. Syst. Bacteriol. 1997, 47, 1145-1156. [CrossRef]

67. Diamant, A.; Colorni, A.; Ucko, M. Parasite and disease transfer between cultured and wild coastal marine fish. CIESM Work Monogr. 2007, 32, 49-53.

68. Butler, J.R.A. Wild salmonids and sea louse infestations on the west coast of Scotland: Sources of infection and implications for the management of marine salmon farms. Pest. Manag. Sci. 2002, 58, 595-608. [CrossRef]

69. Krkošek, M. Host density thresholds and disease control for fisheries and aquaculture. Aquac. Environ. Interact. 2010, 1, 21-32. [CrossRef] 
70. Uglem, I.; Dempster, T.; Bjørn, P.A.; Sanchez-Jerez, P.; Økland, F. High connectivity of salmon farms revealed by aggregation, residence and repeated movements of wild fish among farms. Mar. Ecol. Prog. Ser. 2009, 384, 251-260. [CrossRef]

71. Raynard, R.; Wahli, T.; Vatsos, S.M.I. Review of disease interactions and pathogen exchange between farmed and wild finfish and shellfish in Europe. DIPNET Proj. Rep. 2007, 11, 1-35.

72. Arechavala-Lopez, P.; Uglem, I.; Fernandez-Jover, D.; Bayle-Sempere, J.T.; Sanchez-Jerez, P. Post-escape dispersion of farmed seabream (Sparus aurata L.) and recaptures by local fisheries in the Western Mediterranean Sea. Fish. Res. 2012, 121, 126-135. [CrossRef]

(C) 2020 by the authors. Licensee MDPI, Basel, Switzerland. This article is an open access article distributed under the terms and conditions of the Creative Commons Attribution (CC BY) license (http://creativecommons.org/licenses/by/4.0/). 